\title{
CARROT JUICE FOR POST PARTUM MOTHER: AN INTRODUCTION TO VEGETABLE CONSUMPTION
}

Gusti Ayu Tirtawati ${ }^{1}$, Fonnie Kuhu ${ }^{2}$, Stevany Gaby Makarau ${ }^{3}$

${ }_{1,2,3}$ Department of Midwifery, Health Polytechnic of Manado, Ministry of Health

\section{INFORMASI ARTIKEL:}

\section{Riwayat Artikel:}

Tanggal diterima: September 2020

Tanggal di revisi: September 2020

Tanggal di Publikasi: Oktober 2020

Key Word : breast milk, nursing mother, vegetable, carrot juice

\section{A B S T R A C T}

\section{INTRODUCTION}

The puerperium is the 6-8-week period from the time of delivery of the placenta up to the resumption of normal ovulation.[1] At the same time, the production of breast milk starts to occur;[2] consequently, breastfeeding as a process where a baby receives milk from mother's breast must be initiated.[3] Exclusive breastfeeding is done, regarding the time after birth to six months or until reaching two years of age, the sucking and swallowing from the baby's mouth is directly to the mother's nipple.[4] It is a way of feeding that is given directly by mothers to their children, as a learning process for babies to suck milk out of the breasts efficiently and, at the same time, mothers learn how to breastfeed babies as comfortably as possible.[5,6]

Newborns breastfeed ranging from 10 to 12 times every 24 hours.[7] A healthy baby will empty the breast for about 5-7 minutes, while the milk in the baby's stomach will empty within 2 hours. Breastfeeding management is all the efforts made to help mothers achieve success in breastfeeding their babies. It has two definitions, i.e., the production of breast milk (prolactin reflex) and the release of breast milk by oxytocin (flow reflex or let down reflect). The main factor that influences this is hormonal factors, i.e., the prolactin which plays a role in stimulating the release of breast milk. One substance that can help the process of milk secretion in cows by increasing the production of the prolactin is beta carotene.[8] This may be the basic that the substance may work also in humans.

Carrot (Daucus carora L.) is a root vegetable plant that has high beta carotene content, is rich in dietary fiber and natural antioxidants, and has high vitamin $\mathrm{A}$, which is 12,000 IU.[9] The active compound contents of carrots are, among others, protein, carbohydrates, fat, fiber, natural sugars, pectin, glutatin, asparaginine, geraniol, flavonoids, pinene, limonene and beta carotene with carotene that gives carrots their characteristic orange color.[10] The reddish yellow color also indicates vitamin $\mathrm{B}$, vitamin $\mathrm{C}, \mathrm{D}, \mathrm{E}$, and $\mathrm{K}$ and minerals. 
Based on the results of the preliminary survey at the Tuminting Health Center in Manado City, the number of breastfeeding mothers reached 703 people. Based on the results of interviews with 11 mothers, 4 of them stated that breast milk was not expressed smoothly. This was because they did not like to consume foods that could facilitate breastfeeding such as green vegetables. Seven of them stated that breast milk was released smoothly because they consumed adequate milk, green vegetables, and nuts to facilitate breastfeeding. Based on this preliminary survey, there was a need for a qualitative study to understand the underlying reasons on why women still had no interest in consuming green vegetables.

\section{METHOD}

This qualitative study used a phenomenological approach. This study was conducted at the Tuminting Public Health Center in Manado City in June 2019. The population in this study was all postpartum mothers who breastfed their 0-6 months babies at the working area of Tuminting Health Center in Manado City. Sampling was done by means of accidental sampling, i.e., the technique of determining the sample based on by chance, i.e., those who accidentally met the researchers who could be used as a sample as long as the person met the sample criteria.

The sample criteria were postpartum mothers who were willing to be respondents by filling up the informed consent and breastfed their babies 0-6 months. The sample obtained was finally 4 samples. The instruments used were a questionnaire specific to ask the reasons why they preferred not to consume green vegetables. Furthermore, they were initiated the taste of vegetable juice, i.e., by choosing carrot as the first vegetable. This research has been approved by the Ethics Commission for Manado Healh Polytechnic

\section{RESULT AND DISCUSSION}

this study, all of the mothers just had one child, meaning that the baby was their first child. Based on age, two of them were 25 years old or less category and two of them belonged to the more than 25 years old category. All of them also graduated from senior high school and did not have any specific job other than being a mother in their household.

Table 1. Respondents' Characteristics

\begin{tabular}{|c|c|c|c|}
\hline NO & Characteristic & $\mathbf{N}$ & $\%$ \\
\hline 1. & $\begin{array}{l}\text { Parity } \\
1 \\
>1\end{array}$ & $\begin{array}{l}4 \\
-\end{array}$ & $\begin{array}{l}100 \\
-\end{array}$ \\
\hline 2. & $\begin{array}{l}\text { Age } \\
\leq 25 \\
>25\end{array}$ & $\begin{array}{l}2 \\
2\end{array}$ & $\begin{array}{l}50 \\
50\end{array}$ \\
\hline 3. & $\begin{array}{l}\text { Education } \\
\text { College } \\
\text { Senior High } \\
\text { Junior High }\end{array}$ & $\begin{array}{l}- \\
4 \\
-\end{array}$ & $\begin{array}{l}- \\
100 \\
-\end{array}$ \\
\hline 4. & $\begin{array}{l}\text { Employement } \\
\text { Working } \\
\text { Homemaker }\end{array}$ & - & $\begin{array}{l}- \\
100\end{array}$ \\
\hline
\end{tabular}

\section{Reasons for not liking vegetables}

\section{a. Not used to consuming vegetables since childhood}

The respondents answered that they did not like vegetables because they were not used to eating vegetables since they were young. Therefore, this habit carried over until they were adults and even had children. This was conveyed by one of them,

"I am not used to eating vegetables since I was little. Every time I eat, I prefer a lot of side dishes over vegetables." (R1) 
Other respondents also had an answer that was in line with that answer,

"I think vegetables taste strange so I don't get used to eating vegetables, especially green vegetables." (R4)

\section{b. The ignorance of the benefits of vegetable for breastfeeding}

The respondents in fact already know that vegetables have a positive impact on their health. However, they do not know that vegetables are also very beneficial for their milk production. This is what they have just realized.

"I just found out that vegetables also play an important role in the production of breast milk. However, regarding the benefits of vegetables for health, I have known for a long time, but still I'm lazy to eat vegetables. " (R2)

"Vegetables are good according to people's opinion and also the information I hear. However, I do not know that vegetables can also provide benefits for the large amount of breast milk production. I should have forced me to eat vegetables since I was young so I want to eat vegetables. " (R3)

\section{Opinions after consuming carrot juice}

After they expressed the reasons that they did not really like eating vegetables, the respondents were asked to try the vegetables in the form of juice, namely carrots that had been extracted and filtered. The opinions of the four respondents were:

"I was still hesitant to drink juice because maybe as far as I remember it was the first time I drank vegetable juice. Usually, I only drink fruit juice. That too is rare. However, after I drank it, I felt a comfortable fresh sensation in my body. The taste is sweet too, very good.” (R1)
"Earlier, when I was drinking, I took a small sip. It turned out that carrot juice is delicious. It didn't taste like what I imagined." (R2)

"I liked the taste. However, this was carrot juice not other green vegetables such as spinach or mustard greens. Maybe this carrot juice can be a good start for me to enjoy the vegetables later." (R3)

"It's delicious. I could drink up to one glass. But I don't know if making it will be difficult or not. However, carrot juice is delicious even without sugar." (R4.

Nutrition is very important to provide basic information to pregnant women. [11] Eating a variety of healthy foods, such as vegetables and fruit for pregnant women, is the right step in supporting the growth and development of the fetus in the womb.[12] There are many variations of vegetables and fruits that can be consumed by pregnant women. Various vegetables and fruits for pregnant women can help meet various important nutrients needed for fetal development.

By eating the right kinds of fruits and vegetables, it will help optimize the child's growth and development. Being a smart mother, of course, will not forget to pay attention to every nutritional intake received during pregnancy. It is due to the fact that every food and drink consumed can have an impact on the growth and development of the little one in the womb.

Fruits and vegetables contain essential and essential nutrients such as vitamins, fiber, minerals and antioxidants. This nutritional content is very important for mothers who are undergoing pregnancy.[13] Being smart in choosing variations in the consumption of fruits and vegetables will greatly determine the quality of the health of the pregnancy. Other important content such as carotene, folate, and 
magnesium are also very beneficial for the growth process of the fetus.

Consumption of fruits and vegetables during pregnancy also has an impact on the quality of the baby's health and weight during labor. By consuming nutrient-rich fruits and vegetables at every intake, the chances of the little one being born with an ideal body weight will be even higher. In addition, the little one will have a better immune system and avoid the risk of getting sick. Eating a variety of fruits and vegetables with a variety of colors, ranging from green, yellow and orange, holds indeed many benefits.

Antioxidants found in fruits and vegetables are useful to protect the fetus' cells from the threat of free radicals from the environment around the mother which is dangerous. Consuming balanced amounts of fruits and vegetables will also protect the little one from the risk of developing allergies. Some examples of the benefits of fruits and vegetables during pregnancy include consumption of leafy types of vegetables and also consumption of apples that will prevent your little one from the risk of developing respiratory diseases, vitamin $\mathrm{E}$ found in spinach, broccoli, and pumpkin leaves that can protect the fetus one from the risk of developing asthma, and green and yellow fruits and vegetables that contain lots of beta-carotene such as carrots, sweet potatoes, and oranges function to reduce the risk of skin eczema.

In relation to breast milk as the best food for babies, a mother must have adequate nutrition, so that her breast milk is of good quality. Papaya leaf, for example, is rich in folic acid, vitamin $A$, vitamin $C$, and potassium. There is also iron so papaya leaf is believed to help facilitate breastfeeding.[14] In addition, this fruit which is low in saturated fat, sodium, and cholesterol can help smooth the mood of mothers who are tired of caring for babies.
Papaya is better eaten directly, but also delicious when made into juice.

Katuk leaves have many benefits, one of which is to facilitate breastfeeding. That is why, since ancient times, nursing mothers have always been advised to consume vegetables that contain several vitamins such as vitamin $A$, vitamin $B$, and vitamin $C$. Other ingredients are iron, protein, carbohydrates, fats, and others.[15] In addition, Carrots are known to be good for eye health. However, it turns out that the beta carotene and vitamin content in carrots is also beneficial for breast milk production and increases energy for the mother. The latter is used as the initial introduction for the respondents of this study to start consuming vegetales.

In this study, the respondents disliked vegetables since they were young. The underlying apriori with regard to food preferences is that people choose to eat some other food. The implication, some foods are avoided. The fact that certain foods are not eaten is implicit in existing research on food choices, but is included in the explicit list.[16]

What was found in this study actually happened not only in this research location but in all communities of the world. Of course, this should be prevented as early as possible by cutting off opportunities for children who do not like vegetables so that this habit does not carry over into adulthood. What people do not eat varies over time. [17] The case that occurred in this study was the dislike of breastfeeding mothers towards the consumption of vegetables since they were young, which may have an impact on their milk production. Therefore, information that can reach every level of society about the importance of vegetable consumption is needed. 


\section{CONCLUSION}

The dislike of consuming vegetables since childhood, especially girls, may have an impact on milk production when they are breastfeeding. This study focuses on the reasons the respondents disliked vegetables, which turned out that they started from childhood. These findings may be used as inspiration for further research on the theme of consumption of vegetables during pregnancy and postpartum for more milk production by involving many respondents and sufficient time.

\section{REFERENCE}

Brännström, L., Vinnerljung, B., \& Hjern, A. Tulchinsky, T. H., \& Varavikova, E. A. (2014). Family Health. The New Public Health, 311-379. doi:10.1016/b978-0-12415766-8.00006-

Guo, M. (2014). Introduction: trends and issues in breastfeeding and the use of infant formula. Human Milk Biochemistry and Infant Formula Manufacturing Technology, 116. doi:10.1533/9780857099150.1

Cohen, S. S., Alexander, D. D., Krebs, N. F., Young, B. E., Cabana, M. D., Erdmann, P.,Saavedra, J. M. (2018). Factors Associated with Breastfeeding Initiation and Continuation: A Meta-Analysis. The Journal of Pediatrics. doi: 10.1016/j.jpeds.2018.08.008 Sitepoe , M. 2013. ASI Ekslusif: Arti Penting Bagi Kehidupan. Jakarta : Indeks pp. 2426,30,82-83

Ramiro González, M. D., Ortiz Marrón, H., Arana Cañedo-Argüelles, C., Esparza Olcina, M. J., Cortés Rico, O., Terol Claramonte, M., \& Ordobás Gavín, M. (2018). Prevalence of breastfeeding and factors associated with the start and duration of exclusive breastfeeding in the Community of Madrid among participants in the ELOIN. Anales de Pediatría (English Edition), 89(1), 3243. doi:10.1016/j.anpede.2017.09.004
De Roza, M. J. G., Fong, M. M. K., Ang, M. B. L., Sadon, M. R. B., Koh, M. E. Y. L., \& Teo, M. S. S. H. (2019). Exclusive breastfeeding, breastfeeding self-efficacy and perception of milk supply among mothers in Singapore: A longitudinal study. Midwifery, 79, 102532. doi:10.1016/j.midw.2019.102532

Gilley, S. P., \& Krebs, N. F. (2020). Infant nutrition. Present Knowledge in Nutrition, 3 22. doi:10.1016/b978-0-12-818460-8.00001-0

De Ondarza, M. B., Wilson, J. W., \& Engstrom, M. (2009). CASE STUDY: Effect of Supplemental $\beta$-Carotene on Yield of Milk and Milk Components and on Reproduction of Dairy Cows. The Professional Animal Scientist, 25(4), 510-516. doi:10.15232/s10807446(15)30742-7

Shukla, S. K., \& Kumar, V. (2013). Bioactive Foods and Supplements for Protection against Liver Diseases. Bioactive Food as Dietary Interventions for Liver and Gastrointestinal Disease, ～557-567. doi:10.1016/b978-0-12397154-8.00019-1

Tanumihardjo, S. A., Suri, D., Simon, P., \& Goldman, I. L. (2016). Vegetables of Temperate Climates: Carrot, Parsnip, and Beetroot. Encyclopedia of Food and Health, 387-392. doi:10.1016/b978-0-12-3849472.00714-5

Kominiarek, M. A., \& Rajan, P. (2016). Nutrition Recommendations in Pregnancy and Lactation. Medical Clinics of North America, 100(6), 1199-1215. doi:10.1016/j.mena.2016.06.004

Miyake, Y., Tanaka, K., Okubo, H., Sasaki, S., \& Arakawa, M. (2019). Maternal consumption of vegetables, fruit, and antioxidants during pregnancy and risk of childhood behavioral problems.

Nutrition, 110572. doi:10.1016/j.nut.2019.110572

Prentice, A. (2004). Nutrition and pregnancy. Women's Health Medicine, 1(1), 2224. doi:10.1383/wohm.1.1.22.55411 
Ikhlasiah, M., Winarni, L. M., Poddar, S., \& Bhaumik, A. (2020). The effects of papaya leaf juice for breastfeeding and working mothers on increasing prolactin hormone levels and infant's weight in Tangerang. Enfermeria Clínica, 30, 202205. doi:10.1016/j.enfcli.2019.11.054

Soka, S., Alam, H., Boenjamin, N., Agustina, T. W., \& Suhartono, M. T. (2010). Effect of Sauropus androgynus Leaf Extracts on the Expression of Prolactin and Oxytocin Genes in Lactating BALB/C Mice. Journal of Nutrigenetics and Nutrigenomics, 3(1), 31-36. doi: $10.1159 / 000319710$

MacClancy, J., Henry, J., \& MacBeth, H. (Eds.). (2007). Consuming the inedible. Neglected dimensions of food choice. Oxford: Berghahn.

Uprichard, E., Nettleton, S., \& Chappell, P. (2013). "Food hates" over the life course: an analysis of food narratives from the UK Mass Observation Archive. Appetite, 71, 137. doi:10.1016/j.appet.2013.08.003 